\title{
Politician personality, Machiavellianism, and political skill as predictors of performance ratings in political roles
}

\author{
Jo Silvester ${ }^{\prime *}$, Madeleine Wyatt ${ }^{2}$ and Ray Randall ${ }^{3}$ \\ 'Cass Business School, City University London, UK \\ ${ }^{2}$ Kent Business School, University of Kent, UK \\ ${ }^{3}$ School of Business and Economics, University of Loughborough, UK
}

\begin{abstract}
This study conceptualizes politicians as political workers. It describes a multimethod study with two aims: (I) to determine whether politicians share a latent mental model of performance in political roles and (2) to test hypothesized relationships between politician self-rated characteristics (i.e., extroversion, neuroticism, conscientiousness, Machiavellianism, and political skill) and received performance ratings from political colleagues and officers. Two hundred and thirty-one local politicians provided self-ratings on a political performance questionnaire developed following a role analysis, and standardized measures of personality. One hundred and eighty-five also received performance ratings from colleagues $(n=749)$ and officers $(n=729)$. Exploratory and confirmatory factor analyses of self- and received performance ratings revealed five latent factors: Resilience (RS), Politicking, Analytical Skills (AS), Representing People, and Relating to Others. Regression analyses found that neuroticism and conscientiousness contribute to received ratings of RS, and neuroticism contributes to received ratings of AS.
\end{abstract}

\section{Practitioner points}

- As political roles require political work, we argue there is potential to use research and practice from I/ O psychology to improve politician performance.

- The existence of shared latent constructs of performance provides a basis for differentiated criterion assessment in political roles.

- Evidence that individual differences contribute to political performance can be used to shape support activities for individuals in elected roles.

The relationship between personality and politics is one of the oldest and most frequently debated topics in political psychology (Jost \& Sidanius, 2004); a key assumption being that politician characteristics will influence how they perform political roles (cf. Dietrich, Lasley, Mondak, Remmel, \& Turner, 2012; Mondak, Hibbing, Canache, Seligson, \& Anderson, 2010; Simonton, 1998; Winter, 1998). As yet, however, no study has investigated whether politicians' self-rated personality characteristics predict received ratings of their in-role political performance.

This study takes a novel approach. By conceptualizing performance in political roles as political work, we draw on the now extensive research literature on predictors of

*Correspondence should be addressed to Jo Silvester, Cass Business School, City University London, 106 Bunhill Row, London ECIY 8TZ, UK (email: jo.silvester.I @city.ac.uk). 
employee performance from industrial-organizational (I/O) psychology (e.g., Barrick \& Mount, 1991; Schmidt \& Hunter, 2004) to explore the nature of good and poor performance in political roles, and the individual differences that may influence it. We do this using methods commonly found in selection research and practice (i.e., role analysis and multisource feedback), but rarely applied in the political sphere (Silvester, 2012).

The paper describes a multimethod study with two aims: First, to determine whether politicians and employed officers in UK local government share a latent mental model of behaviours associated with political performance, and secondly, to investigate whether politician self-rated personality characteristics (i.e., extroversion, conscientiousness, neuroticism, political skill, and Machiavellianism) predict their day-to-day in-role performance as rated by political colleagues and officers.

A qualitative role analysis was undertaken to identify behavioural indicators for different areas of competence required by local politicians. These behaviours were used to develop self- and observer versions of a political performance questionnaire (PPQ_S and PPQ_O). Two hundred and thirty-one politicians completed the PPQ_S and personality measures, and 185 of these also received ratings from political colleagues and officers on the PPQ_O. Exploratory and confirmatory factor analyses were performed to identify latent constructs of political performance, which were then used to test the study hypotheses.

The research advances existing research on political performance in two ways. First, it addresses calls by researchers for more research using large- $N$ samples of self-report data from politicians (e.g., Best, 2011; Dietrich et al., 2012; Simonton, 1998). Secondly, we believe it is the first empirical study to investigate politician self-rated characteristics and received performance ratings of day-to-day political behaviour.

\section{Personality in politics}

There is a long history of interest in personality and political behaviour. In the aftermath of World War II, early empirical work sought to identify personality constructs associated with motivation to achieve and retain power (Adorno, Frenkel-Brunswik, Levinson, \& Sanford, 1950; Christie \& Geis, 1970; Lasswell, 1948). Later studies focused on the relationship between personality and political ideology (Anderson, 2009; Caprara \& Zimbardo, 2004; Vecchione \& Caprara, 2009), and political behaviour in the workplace (Biberman, 1985; Drory \& Gluskinos, 1980; Grams \& Rogers, 1990). More recently, there has been growing interest amongst management scholars in the characteristics needed for effective political leadership at work (Ammeter, Douglas, Gardner, Hochwarter, \& Ferris, 2002; Ferris et al., 2008).

Of particular relevance here, however, are studies that have sought to identify individual characteristics associated with successful performance in political roles (cf. Barber, 1972; George \& George, 1998; Hermann, 1980; House, Spangler, \& Woyke, 1991; Kowert, 1996; Lyons, 1997; McCann, 1992; Simonton, 2006; Spangler \& House, 1991).

Most of this work has focused on the personality of significant public figures (US presidents in particular) and relied on 'at-a-distance' methodologies to infer personality characteristics from analysis of secondary source material such as videos of political speeches or transcripts of interviews. For example, Simonton (1988) coded biographical material for 39 US presidents to identify personality characteristics associated with presidential performance, and Winter $(1987,1998)$ rated transcripts of presidential campaign speeches and inaugural addresses to study presidential motivation. Other 
researchers have asked observers to rate personality traits of politicians using established measures (Deluga, 1998; Rubenzer, Faschingbauer, \& Ones, 2000). But politicians are a notoriously difficult group for researchers to access (Caprara \& Zimbardo, 2004; Simonton, 1998), and only a handful of studies involve politician self-ratings; most of which are concerned with politician personality and political ideology.

Costantini and Craik (1980) found that Republicans in the US California campaigns (1960-1976) rated themselves higher than Democrats on personal adjustment, order, self-control and discipline on the Adjective Check List (Gough, 1960), but lower on change and compassion. Similarly, Caprara, Barbaranelli, Consiglio, Picconi, and Zimbardo (2003) found that centre-right members of the Italian Parliament and Italian members of the European Parliament rated themselves higher on energy (extroversion) and conscientiousness than those on the centre-left.

More recently, two studies comparing self-rated personality amongst politicians with that of the general public (Best, 2011; Caprara, Francescato, Mebane, Sorace, \& Vecchione, 2010) found that politicians score higher on extraversion and openness to experience, but lower on neuroticism, agreeableness, and conscientiousness. The researchers conclude that political roles may require extroversion and openness.

Yet, these studies tell us little about whether individual characteristics predict effectiveness in political roles and, as far as we are aware, only two studies have investigated politicians' self-rated characteristics and role performance. Dietrich et al. (2012) asked US legislators $(n=91)$ to complete on-line personality and role attitude questionnaires and found that legislators who scored higher on extraversion and emotional stability were also more interested in standing for higher political office. The researchers suggest that these traits may therefore influence political performance via their impact on political ambition. But without independent performance data, it is not possible to differentiate between interest in higher office and competence to achieve it.

Silvester and Dykes (2007) address this issue in a longitudinal study of candidate performance in the 2005 UK general election. Prospective Parliamentary candidates completed a series of exercises and a critical thinking skills questionnaire as part of an assessment centre run by a political party to identify individuals suited to becoming Members of Parliament (MP). Comparing assessment centre ratings with subsequent election performance, the researchers found that critical thinking skills predicted the percentage of votes and percentage swing in votes ${ }^{1}$ that parliamentary candidates achieved in their constituencies. Based on these findings, Silvester and Dykes suggest that cognitive ability may be as important for performance in political roles as it is for performance in other types of jobs (Schmidt \& Hunter, 2004).

\section{Political performance}

Although obtaining self-report data from politicians is difficult, a potentially greater challenge for research lies in defining what constitutes good and poor political performance. Electoral performance has often been used as a proxy for political performance, but this can depend more on how political parties are performing nationally than the actions of individual candidates (Lodge, Steenbergen \& Braus, 1995). More

\footnotetext{
' Percentage swing is calculated as the difference in the proportion of votes secured by a political party in a specific constituency between the 2001 and 2005 general elections.
} 
importantly, electoral performance provides little insight into the day-to-day role performance of elected representatives.

Most studies of employee performance address this criterion problem using managers' ratings (Arvey \& Murphy, 1998), but politicians are not managed and they do not have pre-defined performance standards. As democratically elected representatives, politicians have a legitimate right to define their roles and what constitutes good and poor performance (March \& Olsen, 1999; Morrell \& Hartley, 2006; Silvester, 2012). Political performance is also contested because it can be judged good, bad, or both, depending on how different stakeholders believe the elected representative should enact their role (Silvester, 2008).

In the absence of pre-defined performance constructs, our solution was to investigate what local politicians conceptualize as good and poor role performance. We used role analysis to identify behaviours and competencies associated with different areas of the local politician role and develop self- and observer-rated performance questionnaires. These questionnaires were then used to capture and analyse large- $N$ data sets, to investigate shared latent mental constructs of performance and test hypothesized relationships with politician personality.

\section{Individual characteristics and politician performance}

Numerous personal qualities have been theorized as important for political roles. We narrowed our focus by drawing on research into predictors of employee performance, and studies of political behaviour amongst political elites and the general public, to identify five characteristics likely to influence political performance: Conscientiousness, extroversion, neuroticism, Machiavellianism, and political skill.

\section{Conscientiousness}

Of the Big Five personality traits, conscientiousness demonstrates the most consistent and significant impact on job performance (Barrick \& Mount, 1991; Salgado, 1997). More conscientious individuals tend to be achievement oriented, reliable, and likely to persevere in the face of set-backs (Bono \& Judge, 2004; Costa \& McCrae, 2006). These qualities are also likely to be important in political roles. For example, politicians must be self-motivated and persistent to overcome opposition and navigate complex ambiguous environments (Morrell \& Hartley, 2006; Simpson, 2008). Mondak and Halperin (2008) also argue that to be successful politicians need the strong sense of duty often associated with conscientiousness. We therefore hypothesized that conscientiousness would be positively associated with self- and received performance ratings and, in particular, with aspects of political roles requiring high levels of diligence, reliability, and persistence (Hypothesis 1).

\section{Extroversion}

Extroverts are more outgoing, sociable, persuasive, and energetic than introverts (Costa \& McCrae, 2006), and research on political engagement has also shown they are more likely to participate in activities such as campaigning, signing petitions, and political rallies (Anderson, 2009; Mondak et al., 2010; Vecchione \& Caprara, 2009). Several researchers theorize that extroversion is important for political performance, because extroverts may find it easier to perform activities such as meeting with constituents, speaking in public, 
and rallying political support (Best, 2011; Caprara et al., 2010; Dietrich et al., 2012). Simonton (1988) also identifies person-orientation (a construct related to extroversion) as an important characteristic for presidential success. We therefore hypothesized that extroversion would be positively associated with self- and received performance ratings, especially in those areas concerned with public engagement (Hypothesis 2).

\section{Neuroticism}

Studies of traditional work have shown a negative relationship between neuroticism, performance, and leadership emergence (Barrick \& Mount, 1991; Judge, Bono, Ilies, \& Gerhardt, 2002; Salgado, 1997), and it seems reasonable to theorize similar relationships in political roles, particularly as these roles are characterized by high levels of conflict, opposition, and interpersonal challenge (Silvester \& Dykes, 2007; Simonton, 1988). As individuals with high neuroticism tend to be more anxious and less able to deal effectively with conflict and criticism (Costa \& McCrae, 2006), we predicted that neuroticism would be negatively associated with self- and received performance ratings in political roles and especially for aspects concerned with coping with pressure and making decisions under stress (Hypothesis 3).

\section{Political skill}

Defined by Ferris et al. (2005, p. 127) as 'the ability to effectively understand others at work and to use such knowledge to influence others to act in ways that enhance one's personal and/or organizational objectives', political skill is a social effectiveness construct that varies from person to person as a consequence of innate ability and practice. Political skill is important for building networks, persuading others, and negotiating consensus and has been found to predict performance ratings for managers and career success (Andrews, Kacmar, \& Harris, 2009; Gentry, Gilmore, Shuffler, \& Leslie, 2012; Todd, Harris, Harris, \& Wheeler, 2009). One might therefore expect it to be important for political performance (Silvester, 2008; Simpson, 2008; Treadway, 2012), although to date there have been no studies of self-rated political skill amongst politicians. We therefore hypothesized that political skill would be positively associated with self- and received performance ratings, particularly for role aspects involving persuasion and relationship building (Hypothesis 4).

\section{Machiavellianism}

Originally defined as a personality disposition reflecting an individual's willingness to control or manipulate others (Christie \& Geis, 1970), Machiavellian employees are more likely to use deceit to influence others (Biberman, 1985; Drory \& Gluskinos, 1980; Grams \& Rogers, 1990). Given popular descriptions of politicians as Machiavellian (Deluga, 2001), one might reasonably predict a positive relationship between Machiavellianism and political performance. Yet, studies have also shown that electoral success depends on whether voters judge a candidate as having integrity and being trustworthy (Deluga, 1998; Pillai, Williams, Lowe, \& Jung, 2003), and a recent meta-analysis also found a small negative correlation between Machiavellianism and employee job performance (O'Boyle, Forsyth, Banks, \& McDaniel, 2012). We therefore predict (counter to popular conceptions of politicians) that Machiavellianism would be negatively associated with received performance ratings for politicians (Hypothesis 5). 


\section{Method}

\section{Research overview and context}

The research had two stages: (1) a qualitative competency analysis eliciting behavioural indicators for good and poor political performance, used to develop a multisource PPQ, and (2) an empirical stage investigating shared latent performance constructs and testing hypothesized relationships between politician characteristics and received performance ratings.

Participants were politicians and employed officers in local authorities throughout England and Wales. Although broadly equivalent to county and city government in the United States, the United Kingdom has no elected legislators or judiciary, and the focus of this study is therefore on community-based politicians (i.e., also known as councillors and elected members) who represent the needs of their constituents in the local authority. Most of these politicians occupied executive roles or the equivalent in opposition, which meant that they were responsible for a specific area (e.g., education or environmental services) and worked alongside employed officers with relevant technical expertise.

\section{Stage I: Competency analysis}

Competency analysis is suited to political roles, because it accepts the existence of a plurality of views about how a role should be performed (Sanchez \& Levine, 2000; Shippmann et al., 2000). Unlike traditional forms of job analysis that focus on identifying the requisite tasks and responsibilities of a role, competency analysis aims to shape a consensus about the range of behaviour role incumbents must demonstrate to perform a role with competence (Wisser, Atlink, \& Algera, 1997).

Competency analysis involves eliciting behaviours associated with good and poor performance from interviews with stakeholders who have different perspectives on a role (i.e., role incumbents and managers). These are then discussed with stakeholders using a reflexive process to refine an emergent constellation of desirable and essential behaviours. The final competencies reflect shared views about how a role should be performed (Kurz \& Bartram, 2002) and provide a basis for assessment tools capable of differentiated criterion measurement (Bartram, 2005).

\section{Procedure}

Stakeholder interviews were conducted with 32 politicians (i.e., seven council leaders, three opposition leaders, two deputy leaders, 14 executive members, and six non-executive members) and 21 officers (i.e., two chief executives and 19 senior officers), recruited using a purposive sampling strategy from 12 local authorities that varied in size, political control, and geographical location. Permission was secured from council Leaders, before contacting politicians and officers by email to invite them to participate in a study investigating the local politician role. All were assured that participation was voluntary and that responses would be anonymized and treated in confidence.

Interviews lasting 30-40 min were audio-recorded and conducted in person. These followed a semi-structured critical incident format (Flanagan, 1954) to elicit examples of good and poor performance in different aspects of the role. Interviewees were asked to recall and describe examples of their own or colleague behaviour in three work areas: Community, local authority, and political group. 


\section{Analysis}

Following Boyatzis (1998), all behaviours were audio-extracted from interviews, recorded on separate cards, and analysed using thematic analysis. Three researchers experienced in role analysis worked independently on a third of the data corpus, grouping together conceptually similar behaviours that described different areas of competence (Braun \& Clarke, 2006), before meeting to compare and discuss emergent themes.

Using a process of reflection and reiteration, agreement was finally reached on nine broad areas of competence (Miles \& Huberman, 1994). Member checks were conducted in three ways. In two focus groups with subject matter experts (i.e., senior representatives from local government, political parties, and senior officers: $N=18$ ), participants were asked to consider whether the emergent competencies fully captured different role areas and to identify six positive and six negative behaviours for each competency describing the range of good and poor performance (Tett, Guternamn, Bleier, \& Murphy, 2000). These competencies and behavioural indicators were also discussed with five of the original interviewees to check for meaning, accepted political language, and comprehensiveness. Finally, a questionnaire was emailed to politicians and officers $(N=240)$ in local authorities, asking them to rate the relevance and importance of each behavioural indicator and to suggest any changes that could improve the analysis. The competences and example behavioural indicators are listed in Table 1.

Table I. Competencies and example behavioural indicators

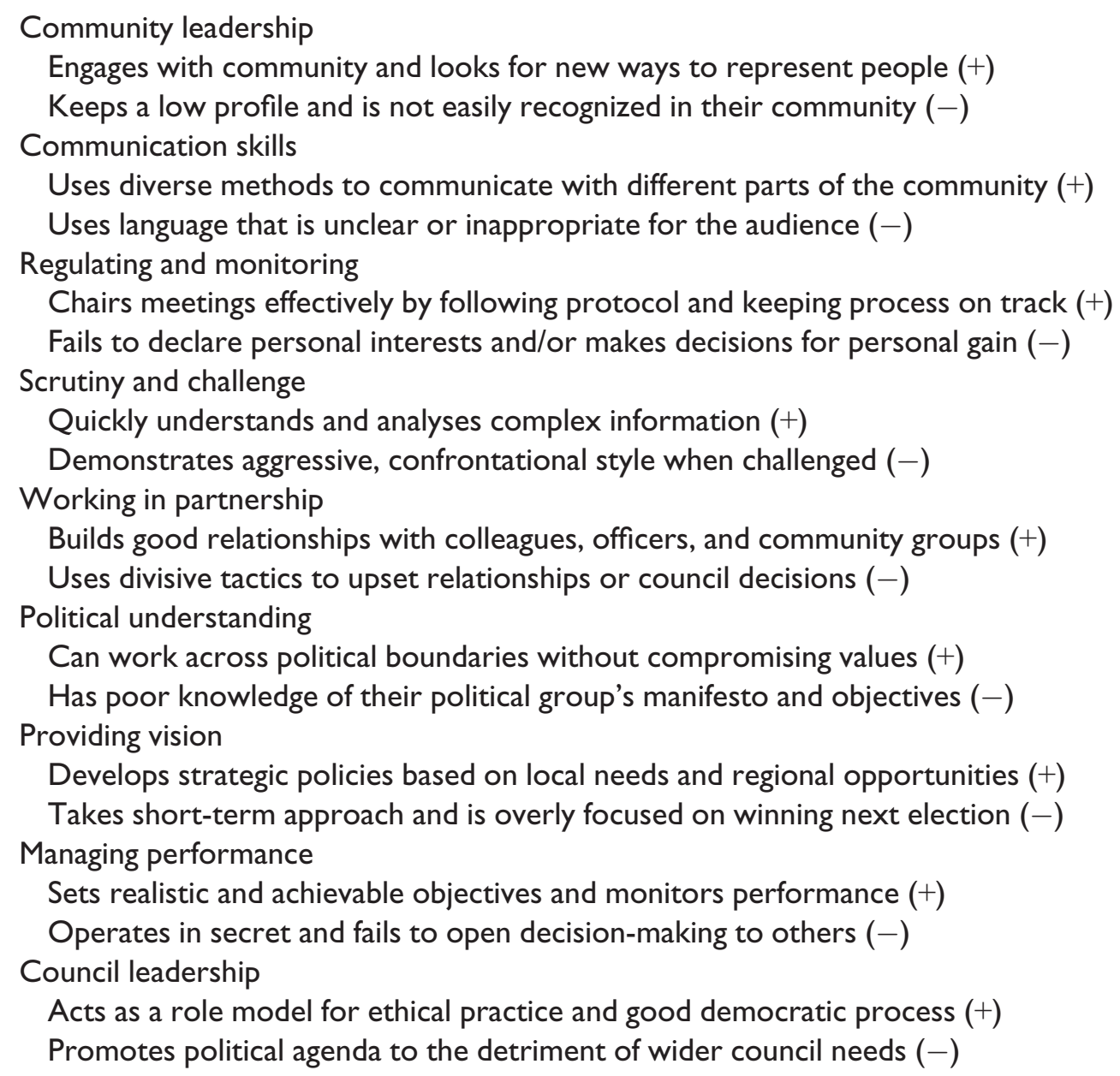


Development and test of a PPQ

Two versions of a multisource PPQ were created using the behavioural indicators (a self-rated version: PPQ_S and an observer-rated version: PPQ_O), allowing further empirical investigation of shared latent constructs of political performance and the study hypotheses.

The questionnaires were created by converting all agreed indicators into items. A few were split or reversed to avoid response bias and preserve item clarity (e.g., 'keeps up-to-date with local concerns by drawing information from diverse sources' became 'it is difficult to keep up to date with local concerns' and 'I draw information from many different people and sources'). Both the PPQ_S and PPQ_O had the same 114 items. In the PPQ_S, respondents are asked whether the item describes their own behaviour (e.g., 'Balancing council, home and other areas of my life is almost impossible' and 'Sometimes there is a need for secrecy when making decisions'). In the PPQ_O, respondents are asked whether the item describes the behaviour of the politician being rated (e.g., ' $\mathrm{X}$ is not able to balance council, home and other areas of their life' and '....X can be secretive when making decisions'). In a few cases, PPQ_S items are reversed on the PPQ_O so that observers can rate observable behaviour (e.g., 'Making time to learn new skills is difficult' becomes 'Makes time to learn new skills'). All items are rated using a 7-point scale $(1$ = strongly disagree, 7 = strongly agree $)$.

\section{Stage 2: Empirical test of study hypotheses}

Participants and procedure

Participants in stage 2 were local politicians on a national leadership development programme between 2006 and 2010. The 12-month programme has four 3-day workshops including talks from senior politicians, training, personal development, and visits to other local authorities. Politicians are usually nominated by their leader as someone with potential to achieve senior roles in local or national government, and separate cohorts (c. 12-24 participants) run for the three political parties.

As part of their personal development, participants can undertake 360-degree review that involves completing the PPQ_S and personality measures. They can also request anonymous feedback from political colleagues and officers in their local authority using the PPQ_O. Politicians are given a letter for raters explaining why feedback is sought and how it can be provided via an on-line link. Participation in this study was voluntary, and all politicians and raters were asked for permission to use their anonymized data for research.

There was no limit to the number of raters providing feedback, but it was recommended that politicians ask three to four officers and three to four political colleagues who could comment objectively on their performance. Raters had 4 weeks to complete the questionnaire, and politicians received confidential feedback via a personalized report from the researchers.

\section{Measures}

Politicians completed the following standardized measures.

Personality. The 240-item NEO Personality Inventory - Revised (NEO PI-R: Costa \& McCrae, 2006) was used to assess extraversion, conscientiousness, and neuroticism. Agreeableness and openness were also assessed although no hypotheses were formulated 
for these traits. The NEO PI-R has been used extensively in studies of work performance (Costa \& McCrae, 2006; John \& Srivastava, 1999), and items are rated using a 5-point scale $(1=$ strongly disagree, $5=$ strongly agree $)$. Previous reliabilities cited in Costa and McCrae (2006) and reliabilities for this study were neuroticism $(\alpha=.92, .81)$, extroversion $(\alpha=.89, .75)$, conscientiousness $(\alpha=.91, .86)$, agreeableness $(\alpha=.87, .74)$, and openness $(\alpha=.89, .58)$.

Political skill. This was assessed using the 18-item Political Skill Inventory (PSI: Ferris et al., 2005). The PSI has four scales (i.e., networking ability, interpersonal influence, social astuteness, and apparent sincerity), but most studies report overall scores for political skill based on responses to all 18 items (Andrews et al., 2009; Harris, Kacmar, Zivnuska, \& Shaw, 2007). These are rated on a 7-point scale ( $1=$ strongly disagree, 7 = strongly agree), and examples include 'I am good at getting people to like me' and 'I understand people very well'. The PSI has demonstrated good internal reliability ( $\alpha=.90$ : Ferris et al., 2005); in this study, reliability was .91.

Machiavellianism. The 20-item Mach IV self-report questionnaire (Christie \& Geis, 1970) was used to assess Machiavellianism. Items are rated on a 7-point scale $(1$ = strongly disagree, 7 = strongly agree $)$, and examples include 'never tell anyone the real reason you did something unless it is useful to do so' and 'it is wise to flatter important people'. Previous studies report internal reliabilities between .60 and .79 (Mudrack \& Mason, 1995); reliability in the present study was .74.

\section{Results}

Two hundred and thirty-one politicians provided self-ratings on the PPQ_S, Mach IV, and PSI (response rate $=88.9 \%$ ), and 137 also completed the NEO PI-R. Politicians were from the three main political parties (Labour $=69$, Liberal Democrat $=71$, and Conservative $=91), 146$ were male $(63.2 \%)$ and most described themselves as 'white' $(n=182$, 79.5\%). Participants were slightly younger $(M=38.7$ years, $S D=9.69)$ and less experienced ( $M=4.1$ years in office, $S D=3.55$ years) than the national average for councillors (IDeA census, 2007). Of those politicians who provided self-ratings, 178 (77.10\%) received PPQ_O ratings from political colleagues and officers $(M=7.74$, $S D=4.78)$. These were provided by 749 politicians and 729 officers.

\section{Factor analyses}

Principle components analysis, with varimax rotation, was used to identify latent constructs in the self-rated (PPQ_S) data as self-ratings were more likely to provide insight into the full breadth of factors. Data were suitable for analysis $(\mathrm{KMO}=0.77$, Bartlett's test of sphericity, $\left.\chi^{2}(1,1,326)=1153.3, p<.0001\right)$. Velicer's $(1976)$ minimum average partial (MAP) test, parallel analysis (O'Connor, 2000), and inspection of the scree plot and eigenvalues suggested a nine-factor structure for the original 114 items, although many items cross-loaded.

As the aim of the analysis was to clearly define the content of each factor by a parsimonious set of unambiguous items with minimal cross-loadings (Ferguson \& Cox, 
Table 2. EFA factor structure - politician self-ratings $(n=230)$

Factor I: Resilience (RS; E.V. = 3.95, \% variance $=18.82 \%, \alpha=.74$ )

I. There is frequently too much going on in the community to keep up with $\quad .77$

2. I often receive too many emails and letters to deal with effectively $\quad .72$

3. Balancing council, home, and other areas of my life is almost impossible $\quad .68$

4. It is difficult to keep up to date with local concerns $\quad .66$

5. Making time to learn new skills is difficult $\quad .60$

Factor 2: Politicking (E.V. $=2.45, \%$ variance $=1 \mathrm{I} .68 \%, \alpha=.70$ )

6. Sometimes there is a need for secrecy when making decisions $\quad$.7l

7. It is not always possible to be honest with the public $\quad .70$

8. Sometimes it is necessary to impose solutions $\quad .68$

9. Open communication and co-operation do not always work in politics 66

10. Politics wouldn't be politics without political blood-sports $\quad .62$

Factor 3: Analytical skills (E.V. $=2.16, \%$ variance $=10.29 \%, \alpha=.67$ )

I I. I find it easy to deal with complicated information

I2. My colleagues would say I understand issues very quickly $\quad .77$

13. I feel comfortable dealing with numbers and financial reports $\quad$.6I

I4. I usually feel able to balance public needs and local policy 56

Factor 4: Representing people (E.V. $=1.66, \%$ variance $=7.91, \alpha=.69$ )

I5. I am easily recognized by my constituents $\quad .75$

16. People describe me as courageous in campaigning on behalf of others $\quad .73$

17. Others see me as a role model $\quad .72$

18. People say I communicate my values very clearly $\quad .50$

Factor 5: Relating to others (E.V. $=1.23, \%$ variance $=5.86, \alpha=.7 \mathrm{I}$ )

19. Others describe me as a 'good listener'

20. Others describe me as empathic $\quad .74$

$\begin{array}{ll}21 . \text { Others see me as someone who is easy to approach } & .68\end{array}$

Note. Items loading onto RS are reverse-scored for analyses so that high scores correspond to high RS.

1993), numerous iterations of the factor analysis were carried out to identify core constituent items, with one item (i.e., either a cross-loading item ${ }^{2}$ or an item with no loading $>0.50$ ) being removed at each iteration. This approach to item-reduction can place the content validity of the measure at risk; therefore, all removed items were presented to subject matter experts to determine whether any needed to be re-introduced into the analysis.

In total, 21 items were retained and analysed using Velicer's (1976) MAP test. This suggested a four-factor structure, but subsequent parallel analysis and inspection of scree plot and eigenvalues using PCA all favoured a five-factor solution, which explained $54.56 \%$ of the variance in the data (see Table 2). Self-ratings for all factors were normally distributed, indicating that politicians vary in their perceived ability to perform different aspects of their role.

Factors were labelled by inspecting the items that loaded onto them. Factor one was labelled 'Resilience' (RS), because items describe an individual's ability to cope with multiple conflicting demands. Although raw scores were used in the factor analyses, items are reverse-scored in subsequent analyses so that high scores indicate high RS. Factor two 'Politicking' (PK) has items describing a willingness to engage in secrecy, deception, and

\footnotetext{
${ }^{2} \mathrm{~A}$ cross-loading item was one which loaded at 0.30 or greater on more than one factor, and for which, there was a difference of $<0.15$ between the first and second highest loading.
} 


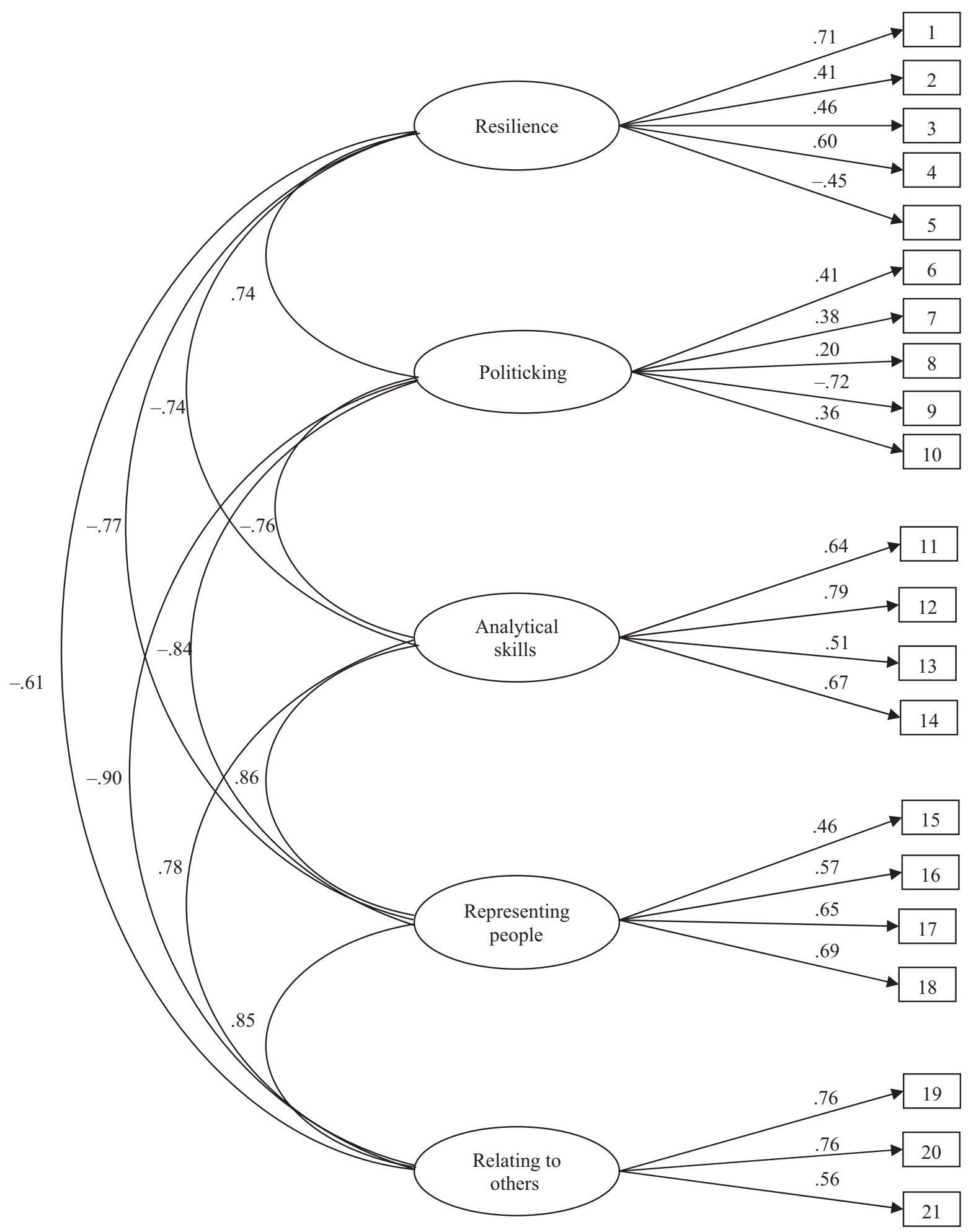

Figure I. Multilevel confirmatory factor analysis using combined received ratings.

Note. $\chi^{2}(379)=1244.5 \mathrm{I}, p<.001, \mathrm{CFI}=0.89$, RMSEA $=0.04$. Within-level standardized coefficients are shown, all paths are $p<.001$. Items 5 and 9 negatively load onto their factors because their wordings were reversed on the PPQ_O, to Makes time to learn new skills and Actively seeks open communication and co-operation in politics, respectively. Resilience (RS) has negative correlations with all factors besides politicking because it was analysed in its raw form. RS was reversed in all further analyses. PPQ, political performance questionnaire. 
political blood sports. Factor three, which has items relating to understanding and analysing complex information, was labelled 'Analytical Skills' (AS), and factor four was labelled 'Representing People' (RP), because its items illustrate engaging with and campaigning for constituents. Factor five was labelled 'Relating to Others' (RO), because items describe listening, being approachable, and empathic.

Two multilevel (two-level) confirmatory factor analyses (MCFA) were conducted on the received ratings (i.e., one each for ratings from political colleagues and officers) using the structural equation modelling program Mplus 6.11 (Muthén \& Muthén, 2011). MCFAs account for the nested nature of the data, where politicians $(n=749)$ and officers $(n=729)$ are nested in rated politicians $(n=178)$, and control for measurement errors at both levels (Dyer, Hanges, \& Hall, 2005). Muthén's (1994) intraclass correlation coefficients (ICC) were first used to determine the extent of systematic between-group variation of the observed PPQ items. These ranged from .05 to .23 with a median ICC of .12 , indicating multilevel analysis was appropriate (Dyer et al., 2005). MCFAs were performed using maximum likelihood estimation, and fit was determined using established criteria (Hu \& Bentler, 1999).

It is normally expected that chi-square should be non-significant, but this statistic can be overly sensitive in larger samples $(N>200$ : Tabachnick \& Fidell, 2001); therefore, fit was determined using RMSEA $(\leq 0.06)$ and CFI $(\geq 0.90)$. Both models reveal a good fit (Political colleagues: $\chi^{2}(379)=797.46, p<.001, \mathrm{CFI}=0.90$, RMSEA $=0.04$, and Officers: $\chi^{2}(379)=753.61, p<.001$, CFI $=0.90$, RMSEA $\left.=0.04\right)$. A third MCFA was conducted to analyse the combined data from political colleagues and officers $(N=1,478)$. Despite a smaller CFI value, the model remained a reasonably good fit $\left(\chi^{2}(379)=1244.51, p<.001, \mathrm{CFI}=0.89, \mathrm{RMSEA}=0.04 \text {, see Figure } 1\right)^{3} ;$ consequently, data from officers and political colleagues were combined to test hypothesized relationships between individual characteristics and received performance ratings.

\section{Test of hypotheses}

Table 3 shows descriptive statistics and correlations between politician characteristics, and self- and received performance ratings for the five political factors. These analyses were based on received ratings (from officers and political colleagues), which were averaged to create a single score for each politician. The correlations between self- and received ratings on the performance factors are significant and, although small, are comparable with other studies and meta-analyses that indicate self-other agreement is typically low in multisource feedback (Conway \& Huffcutt, 1997; Fleenor, Smither, Atwater, Braddy, \& Sturm, 2010).

The study hypotheses were first investigated in relation to correlations between individual characteristics and self- and received ratings for each of the five performance factors. Conscientiousness correlates positively with self-rated AS and RP, and received ratings for RS and AS. A negative correlation with received ratings for PK also approaches significance. This provides partial support for Hypothesis 1, which predicted that conscientiousness would be positively associated with performance ratings, particularly with aspects requiring persistence and a sense of duty.

\footnotetext{
${ }^{3}$ A hierarchical multilevel model was also tested on the combined received ratings to determine whether the five PPQ factors could be accounted for by a single higher order construct (i.e., political competence). Although the model was a good fit according to RMSEA and approached a good fit for CFI $\left(\chi^{2}(394)=1212.48, \mathrm{p}<.00 \mathrm{I}, \mathrm{CFI}=0.88, \mathrm{RMSEA}=0.04\right)$, this was not used in further analyses because the five factor model provides a better conceptual framework for explaining different components of political performance and testing hypotheses.
} 


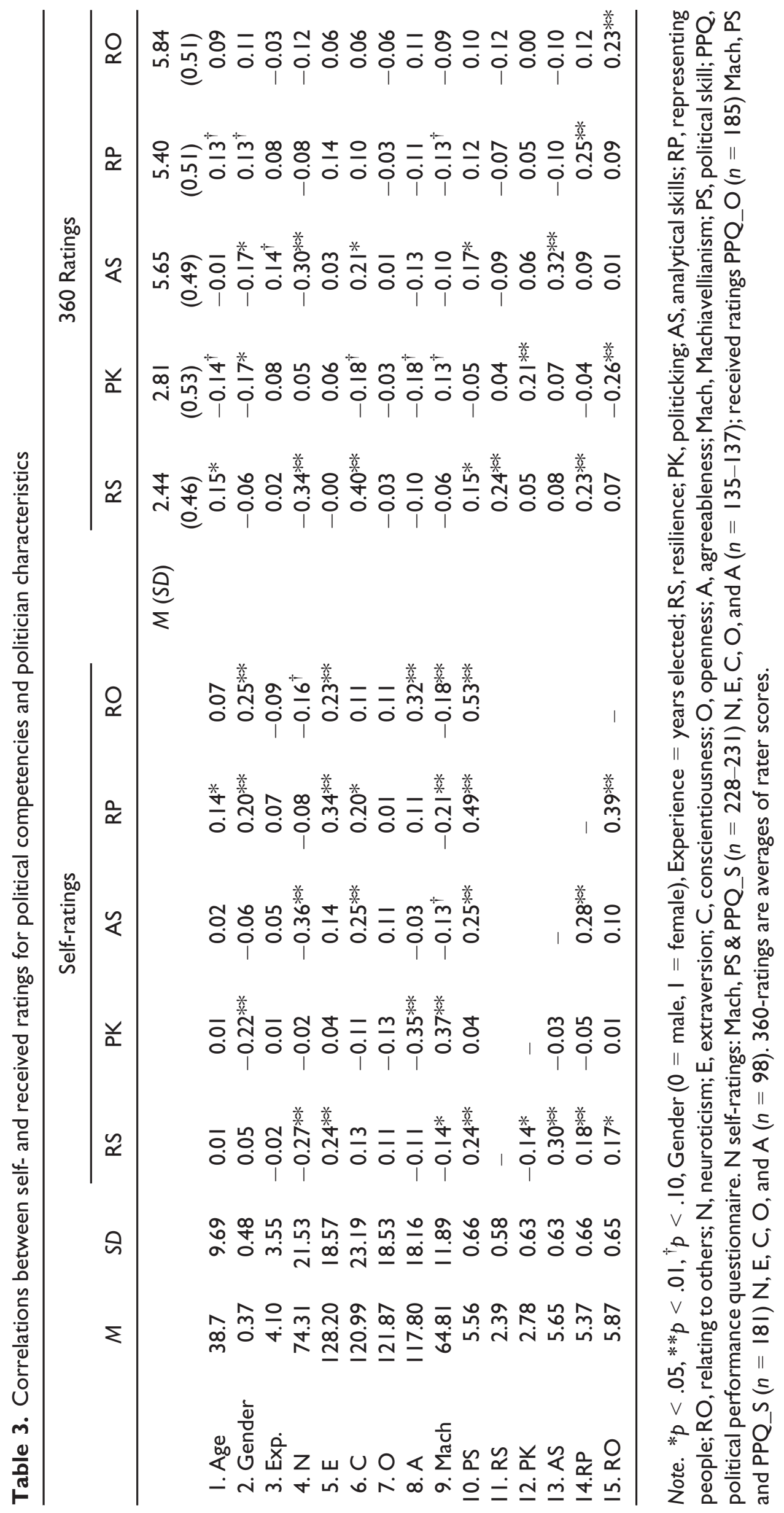




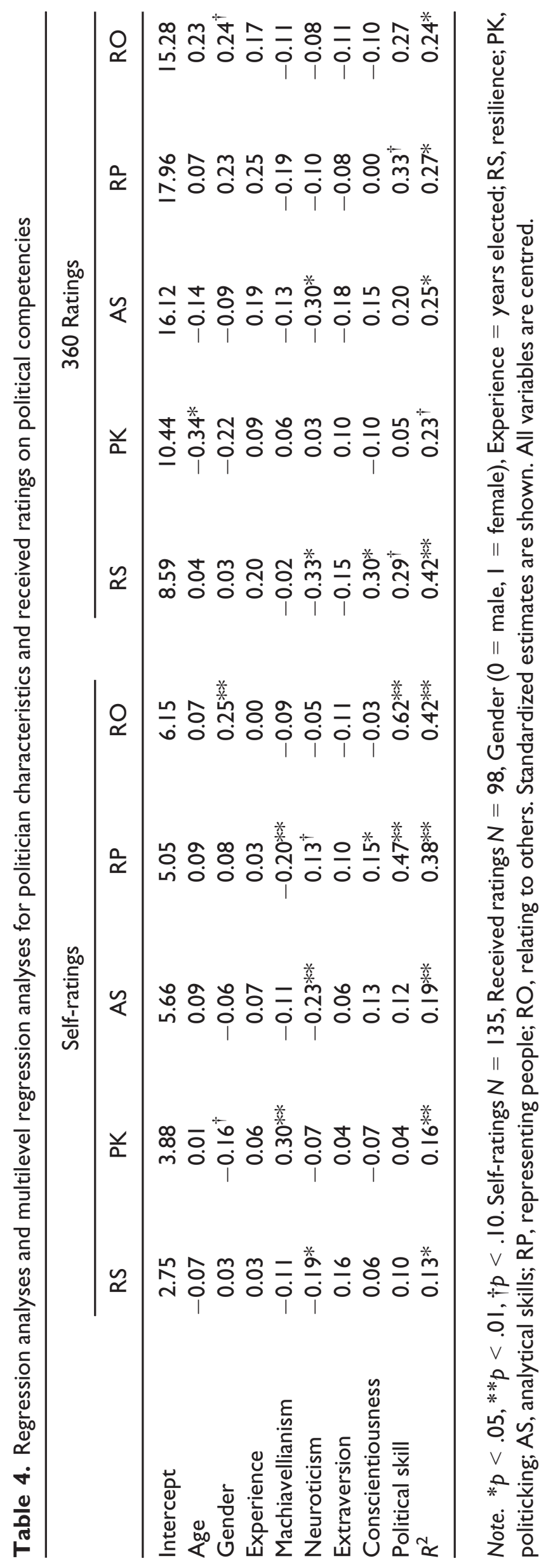


Extraversion correlates positively with self-rated RS, RP, and RO, but not with received ratings for any of the factors; therefore, no strong support was found for Hypothesis 2 . Neuroticism correlates negatively with self- and received ratings for RS and AS, which provides support for Hypothesis 3.

Political skill correlates positively with self- and other-rated RS and AS and with self-rated RP and RO, providing support for Hypothesis 4. Finally, Machiavellianism correlates positively with self-rated PK and negatively with self-rated RS, RP, and RO. A positive correlation with other-rated $\mathrm{PK}$ and a negative correlation with other-rated RP approach significance, providing partial support for Hypothesis 5 as well as some evidence of construct validity.

Additional non-hypothesized findings include a negative correlation between agreeableness and PK and a positive correlation between agreeableness and Representing Others; a negative correlation with other-rated PK also approached significance. Openness does not correlate significantly with any of the study variables. ${ }^{4}$

To examine hypothesized relationships further, regression analyses were conducted using Mplus 6.11, accounting for the nested nature of the data and controlling for age, gender, and experience (Table 4). Multilevel analysis was used for regressions involving received performance ratings. Age, gender, experience, Machiavellianism, neuroticism, extraversion, conscientiousness, and political skill were treated as independent level-one predictor variables. Individual received ratings were treated as level-two variables and were clustered based on politician. This was to account for variability in ratings provided by raters for the same politician as well as between raters in the wider sample.

These analyses show that conscientiousness is a significant predictor of self-rated RP and received ratings of RS, providing further support for accepting hypothesis 1 . Extroversion was not a significant predictor of self- or received ratings, and therefore, Hypothesis 2 is rejected. Neuroticism is significantly associated with self- and received ratings of RS and Analysis and Vision; therefore, Hypothesis 3 was accepted. Political skill is a significant predictor of self-rated RP and RO and approached significance with received ratings of RS and RP. Thus, partial support was found for Hypothesis 4 . Machiavellianism is significantly associated with self-rated PK and RP, but not received ratings; therefore, Hypothesis 5 was rejected. ${ }^{5}$

\section{Discussion}

This research had two aims: (1) to determine whether politicians share a latent mental model of performance in political roles, and (2) to test hypothesized relationships between politician self-rated characteristics and received performance ratings. We addressed these aims using a novel two-stage multimethod study that captured qualitative and quantitative data from politicians, their colleagues, and officers.

\footnotetext{
${ }^{4}$ Non-linear relationships were examined using partial correlations, controlling for linear form, between self- and received factors and quadratic forms of the five characteristics being tested (Ganzach, 1997), but no support was found.

${ }^{5}$ Interactions between political skill and personality (neuroticism, extraversion, and conscientiousness) were also tested as predictors of PPQ factors. Results indicated that neuroticism $\times$ political skill $(\beta=.29, \mathrm{P}<.0 \mathrm{I})$ and conscientiousness $\times$ political skill $(\beta=. I 7, \mathrm{P}<.05)$ were both significant predictors of $R P$, but no other relationships were significant. These interactions suggest that high political skill is associated with higher self-rated RP and is particularly beneficial for individuals with high neuroticism and high conscientiousness. However, low political skill combined with high neuroticism is associated with lower self-rated RP.
} 
Exploratory and confirmatory factor analyses of self- and received ratings revealed five dimensions of political performance (i.e., RS, PK, AS, RP, and RO). This suggests that despite the contested and ambiguous nature of political work, politicians and officers agree about behaviours associated with good and poor performance in different aspects of the role. Politicians deemed to be performing well are judged more resilient, more able to represent and relate to others, and more likely to demonstrate good AS. Good performance was also associated with less PK behaviour, such as dishonesty, secrecy, and political 'blood sports'.

Therefore, whilst politicians may hold different views about what they want to achieve in their political roles (as guided by political ideology and made explicit in their policies and manifesto), they share a common view about how political roles are best performed. Not only does this have implications for debates about the nature of good government and effective political functioning (Searing, 1994), it also suggests practical ways in which individuals might be better prepared for political roles in future (Silvester \& Menges, 2011).

Importantly, the findings also indicate that individual characteristics may impact on effective politician performance. A number of significant and logical associations were found between personality and self-rated politician performance (i.e., agreeableness and Machiavellianism with $\mathrm{PK}$, and extroversion and agreeableness with RO). But of particular, significance is the finding that personality variables predicted received performance ratings: Specifically, neuroticism, conscientiousness, and political skill correlated significantly with politician RS and AS. With a larger $N$ and more power, it is also likely that the correlations between conscientiousness, agreeableness, Machiavellianism, and PK would have reached significance. Extroversion did not correlate significantly with any political factors, and no significant correlations were found between any personality variables and $\mathrm{RO}$, although inspection of the items loading on this factor suggests that future studies might explore whether characteristics such as empathy and emotional intelligence are better predictors of performance in this area. On the basis of these findings, we accepted Hypotheses 1, 3, and 4 and rejected Hypotheses 2 and 5.

Whilst the effect sizes are small to moderate, they compare favourably with meta-analytic research concerned with personality and employee performance (Morgeson et al., 2007; Ones, Dilchert, Viswesvaran, \& Judge, 2007) and are notable given claims that personality is likely to be less important in politics, because politicians are elected rather than selected on the basis of predetermined qualities (Greenstein, 2000). As such, the findings support our contention that (1) parallels can be drawn between political and other types of work, and (2) predictors of employee performance might also help to explain differential performance in political roles.

The findings also make intuitive sense: Neuroticism may be of particular importance in political contexts because politicians work in environments characterized by high levels of conflict, criticism, and stress (Weinberg \& Cooper, 2003); conscientiousness because the ambiguous nature of political roles demands high levels of persistence from incumbents; and political skill because politicians need to forge political alliances, persuade others, and wield influence. Contrary to expectation, extroversion did not predict received ratings. One reason for this may be that whilst extroversion might aid performance in certain role areas such as engaging with others or speaking in public, it could be a disadvantage in those areas that require a quieter, more covert approach (e.g., building political alliances, listening, and keeping counsel). 


\section{Strengths, limitations, and directions for future research}

A major strength of this study is the involvement of politicians in shaping criteria to assess political performance and in providing self-ratings of personality and role performance. A second strength is in the generation of a large- $N$ data set of self- and received ratings that allows empirical study of hypothesized relationships. That said, although at $N=98$ the number of politicians with received ratings is large for this population, it is still small in terms of empirical research and lacks power for multiple analyses. In retrospect, our use of the 240-item NEO P-IR placed considerable demands on respondents, and future studies might benefit from using shorter personality measures to capture large- $N$ data from politicians.

Clearly the findings prompt many questions for further research. For example, are the latent performance constructs found here also shared by politicians in different countries and democratic contexts? Might other characteristics such as proactive personality, intelligence, and political efficacy be important for political effectiveness (Deluga, 1998; Pfeffer, 2010; Silvester \& Wyatt, 2012; Winter, 1998)? Recent research also suggests that political skill moderates the impact of personality variables on work performance (Blickle et al., 2008); therefore, future studies should also explore potential interactions between predictors.

There is also much still to learn about how environmental factors may influence political performance. This study did not control for whether politicians belonged to parties in power or opposition or for the electoral cycle. Yet, in the run up to an election, political colleagues may consider PK behaviour more acceptable or even desirable. Future research might also examine whether successful politicians are simply more skilled at hiding PK behaviour.

Finally, it is worth noting that the study did not explore how members of the public conceptualize political performance. The fact that most people only see a small part of the day-to-day activities of elected representatives presents a real challenge for politicians and political parties, namely how best to convince voters that their elected representatives are working effectively? These findings and similar future research afford the opportunity to foster greater public understanding of the nature and demands of political roles and debate about what can realistically be expected in terms of good performance from our elected representatives.

\section{Practitioner points}

In the United States alone, more than a million people occupy elected roles in government and non-government organizations (Maidment \& Tappin, 1994). Many millions occupy more similar roles across the globe. Yet, despite its importance, political work has been largely ignored by I/O psychology researchers and practitioners (Bar-Tal, 2002; Silvester, 2008).

This research identifies a number of ways in which I/O psychology methods and practice might be applied to political roles in efforts to support and enhance political performance. For example, a shared model of the different competencies and skills required by elected representatives allows creation of more focused and useful development and support, as well as more differentiated criterion assessment.

Yet, there is also a need for caution. Elected representatives differ from employees, and their democratic independence must be acknowledged and respected. This means being aware that practices such as assessment and development operate within human resource systems that are themselves political structures (Ferris \& Judge, 1991; Silvester, 2008). 
To help enhance political effectiveness, I/O psychologists must be sensitive to the need for politicians to retain control over their own development and performance and explore the potential for practices such as 360-degree feedback to accommodate democratic needs.

\section{Conclusion}

A broad aim of this research has been to increase awareness of the importance of political work. Classical political theorists and historians, such as Aristotle, Plato, and Machiavelli, devoted considerable attention to what constitutes good democratic leadership and how it might be achieved (Glad, 2002). By continuing this work and studying politicians as political workers, we argue that I/O psychologists could bring a unique perspective to one of the most important questions for the 21st century, namely how can elected representatives deliver good government?

\section{Acknowledgements}

We would like to thank the Improvement and Development Agency and the Leadership Centre for their support in conducting this research.

\section{References}

Adorno, T. W., Frenkel-Brunswik, E., Levinson, D. J., \& Sanford, R. N. (1950). The authoritarian personality. New York, NY: Harper.

Ammeter, A. P., Douglas, C., Gardner, W. L., Hochwarter, W. A., \& Ferris, G. R. (2002). Toward a political theory of leadership. Leadership Quarterly, 13, 751-796. doi:10.1016/S1048-9843(02) 00157-1

Anderson, M. R. (2009). Beyond membership: A sense of community and political behavior. Political Behavior, 31, 603-627. doi:10.1007/s11109-009-9089-x

Andrews, M. C., Kacmar, K. M., \& Harris, K. J. (2009). Got political skill? The impact of justice on the importance of political skill for job performance. Journal of Applied Psychology, 94, 14271437. doi: $10.1037 / \mathrm{a} 0017154$

Arvey, R. D., \& Murphy, K. R. (1998). Performance evaluations in work settings. Annual Review of Psychology, 49, 141-168. doi:10.1146/annurev.psych.49.1.141

Barber, J. (1972). The presidential character: Predicting performance in the White House. Englewood Cliffs, NJ: Prentice-Hall.

Barrick, M. R., \& Mount, M. K. (1991). The Big Five personality dimensions and job performance: A meta-analysis. Personnel Psychology, 44, 1-26. doi:10.1111/j.1744-6570.1991.tb00688.x

Bar-Tal, D. (2002). The (social) psychological legacy for political psychology. In K. R. Monroe (Ed.), Political psychology (pp. 173-192). Mahwah, NJ: Lawrence Erlbaum.

Bartram, D. (2005). The great eight competencies: A criterion-centric approach to validation. Journal of Applied Psychology, 90, 1185-1203. doi:10.1037/0021-9010.90.6.1185

Best, H. (2011). Does personality matter in politics? Personality factors as determinants of recruitment and policy preferences. Comparative Sociology, 10, 928-948. doi:10.1163/ $156913311 \times 607638$

Biberman, G. (1985). Personality and characteristic work attitudes of persons with high, moderate, and low political tendencies. Psychological Reports, 57, 1303-1310. doi:10.2466/pr0.1985.57. 3f. 1303

Blickle, G., Meurs, J. A., Zettler, I., Solga, J., Noethen, D., Kramer, J., \& Ferris, G. R. (2008). Personality, political skill, and job performance. Journal of Vocational Behavior, 72, 377-387. doi:10.1016/j.jvb.2007.11.008 
Bono, J. E., \& Judge, T. A. (2004). Personality and transformational and transactional leadership: A meta-analysis. Journal of Applied Psychology, 89, 901-910. doi:10.1037/0021-9010.89.5.901

Boyatzis, R. E. (1998). Transforming qualitative information: Thematic analysis and code development. London, UK: Sage.

Braun, V., \& Clarke, V. (2006). Using thematic analysis in psychology. Qualitative Research in Psychology, 3, 77-101. doi:10.1191/1478088706qp063oa

Caprara, G. V., Barbaranelli, C., Consiglio, C., Picconi, L., \& Zimbardo, P. G. (2003). Personalities of politicians and voters: Unique and synergistic relationships. Journal of Personality and Social Psychology, 84, 849-856. doi:10.1037/0022-3514.84.4.849

Caprara, G. V., Francescato, D., Mebane, M., Sorace, R., \& Vecchione, M. (2010). Personality foundations of ideological divide: A comparison of women members of Parliament and women voters in Italy. Political Psychology, 31, 739-762. doi:10.1111/j.1467-9221.2010. 00780.x

Caprara, G. V., \& Zimbardo, P. G. (2004). Personalizing politics: A congruency model of political preference. American Psychologist, 59, 581-594. doi:10.1037/0003-066X.59.7.581

Christie, R., \& Geis, F. L. (1970). Studies in Machiavellianism. New York, NY: Academic Press.

Conway, J. M., \& Huffcutt, A. I. (1997). Psychometric properties of multisource performance ratings: A meta-analysis of subordinate, supervisor, peer and self-ratings. Human Performance, 10, 331-360. doi:10.1207/s15327043hup1004_2

Costa, P. T., \& McCrae, R. R. (2006). Revised NEO Personality Inventory (NEO PI-R) manual. Oxford, UK: Hogrefe.

Costantini, E., \& Craik, K. H. (1980). Personality and politicians: California party leaders, 19601976. Journal of Personality and Social Psychology, 38, 641-661. doi:10.1037/0022-3514.38. 4.641

Deluga, R. J. (1998). American presidential proactivity, charismatic leadership and rated performance. Leadership Quarterly, 9, 265-291.

Deluga, R. J. (2001). American presidential Machiavellianism: Implications for charismatic leadership and rated performance. Leadership Quarterly, 12, 339-363.

Dietrich, B. J., Lasley, S., Mondak, J. J., Remmel, M. L., \& Turner, J. (2012). Personality and legislative politics: The Big Five trait dimensions among U.S. state legislators. Political Psychology, 33, 195-210. doi:10.1111/j.1467-9221.2012.00870.x

Drory, A., \& Gluskinos, U. M. (1980). Machiavellianism and leadership. Journal of Applied Psychology, 65, 81-86. doi:10.1037/0021-9010.65.1.81

Dyer, N. G., Hanges, P. J., \& Hall, R. J. (2005). Applying multilevel confirmatory factor analysis techniques to the study of leadership. The Leadership Quarterly, 16, 145-167. doi:10.1016/j. leaqua.2004.09.009

Ferguson, E., \& Cox, T. (1993). Exploratory factor analysis: A users' guide. International Journal of Selection and Assessment, 1, 84-94. doi:10.1111/j.1468-2389.1993.tb00092.x

Ferris, G. R., Blickle, G., Schneider, P. B., Kramer, J., Zettler, I., Solga, J., .. Meurs, J. A. (2008). Political skill construct and criterion-related validation: A two-study investigation. Journal of Managerial Psychology, 23, 744-771. doi:10.1108/02683940810896321

Ferris, G. R., \& Judge, T. (1991). Personnel human resources management: A political influence perspective. Journal of Management, 17, 447-488. doi:10.1177/014920639101700208

Ferris, G. R., Treadway, D. C., Kolodinsky, R. W., Hochwarter, W. A., Kacmar, C. J., Douglas, C., \& Frink, D. D. (2005). Development and validation of the political skill inventory. Journal of Management, 31, 126-152. doi:10.1177/0149206304271386

Flanagan, J. C. (1954). The critical incident technique. Psychological Bulletin, 51, 327-358. doi: $10.1037 / \mathrm{h} 0061470$

Fleenor, J. W., Smither, J. W., Atwater, L. E., Braddy, P. W., \& Sturm, R. E. (2010). Self-other agreement in leadership: A review. The Leadership Quarterly, 21, 1005-1034. doi:10.1016/j. leaqua.2010.10.006

Ganzach, G. Y. (1997). Misleading interaction and curvilinear terms. Psychological Methods, 2, 235-257. doi:10.1037/1082-989X.2.3.235 
Gentry, W. A., Gilmore, D. C., Shuffler, M. L., \& Leslie, J. B. (2012). Political skill as an indicator of promotability among multiple rater sources. Journal of Organizational Behavior, 33, 89-104. doi:10.1002/job. 740

George, A., \& George, J. L. (1998). Presidential personality and performance. Boulder, CO: Westview Press.

Glad, B. (2002). Political leadership: Some methodological considerations. In L. O. Valenty \& O. Feldman (Eds.), Political leadership for the new century: Personality and behavior among American leaders (pp. 9-24). Westport, CT: Praeger.

Gough, H. G. (1960). The Adjective Check List as a personality assessment technique. Psychological Reports, 6, 107-122. doi:10.2466/PR0.6.1.107-122

Grams, W. C., \& Rogers, R. W. (1990). Power and personality: Effects of Machiavellianism, need for approval and motivation on use of influence tactics. Journal of General Psychology, 117, 71-82. doi:10.1080/00221309.1990.9917774

Greenstein, F. (2000). The presidential difference: Leadership style from Roosevelt to Clinton. New York, NY: Free Press.

Harris, K. J., Kacmar, K. M., Zivnuska, S., \& Shaw, J. D. (2007). The impact of political skill on impression management effectiveness. Journal of Applied Psychology, 92, 278-285. doi:10.1037/0021-9010.92.1.278

Hermann, M. G. (1980). Explaining foreign policy behavior using the personal characteristics of political leaders. International Studies Quarterly, 24, 7-46. Retrieved from: http://www. jstor.org/stable/2600126

House, R. J., Spangler, W. D., \& Woyke, J. (1991). Personality and charisma in the U.S. presidency: A psychological theory of leader effectiveness. Administrative Science Quarterly, 35, 317-341.

Hu, L., \& Bentler, P. M. (1999). Cut-off criteria for fit indexes in covariance structure analysis: Conventional criteria versus new alternatives. Structural Equation Modeling, 6 (1), 1-55. doi:10.1080/10705519909540118

Improvement and Development Agency (2007). National census of local authority councillors in England 2006. Slough, UK: NFER.

John, O. P., \& Srivastava, S. (1999). The Big Five trait taxonomy: History, measurement and theoretical perspectives. In E. Pervin \& O. John (Eds.), Handbook ofpersonality (pp. 102-138). New York, NY: Guildford Press.

Jost, J. T., \& Sidanius, J. (2004). Political psychology. New York, NY: Psychology Press.

Judge, T. A., Bono, J. E., Ilies, R., \& Gerhardt, M. (2002). Personality and leadership: A quantitative and qualitative review. Journal of Applied Psychology, 85, 765-780. doi:10.1037/0021-9010. 87.4.765

Kowert, P. A. (1996). Where does the buck stop? Assessing the impact of presidential personality. Political Psychology, 17, 421-452. doi:10.2307/3791963

Kurz, R., \& Bartram, D. (2002). Competency and individual performance: Modelling the world of work. In I. T. Robertson, M. Callinan \& D. Bartram (Eds.), Organizational effectiveness: The role of psychology (pp. 227-258). Chichester, UK: John Wiley.

Lasswell, H. D. (1948). Power and personality. New York, NY: Norton.

Lodge, M., Steenbergen, M., \& Braus, R. (1995). The responsive voter: Campaign information and the dynamics of candidate evaluation. American Political Science Review, 89, 399-420.

Lyons, M. (1997). Presidential character revisited. Political Psychology, 18, 791-811. doi:10.1111/ 0162-895X.00079

Maidment, R., \& Tappin, M. (1994). American politics today. Manchester, UK: Manchester University Press.

March, J. G., \& Olsen, J. P. (1999). Institutional perspectives on political institutions. In J. G. March (Ed.), The pursuit of organizational intelligence (pp. 52-72). London, UK: Blackwell.

McCann, S. J. H. (1992). Alternative formulas to predict the greatness of U.S. presidents: Personological, situational and zeitgeist factors. Journal of Personality and Social Psychology, 62, 469-479. doi:10.1037/0022-3514.62.3.469 
Miles, M. B., \& Huberman, A. M. (1994). Qualitative data analysis: An expanded source book. London, UK: Sage.

Mondak, J. J., \& Halperin, K. D. (2008). A framework for the study of personality and political behavior. British Journal of Political Science, 38, 335-362. doi:10.1017/S0007123408000173

Mondak, J. J., Hibbing, M. V., Canache, D., Seligson, M. A., \& Anderson, M. R. (2010). Personality and civic engagement: An integrative framework for the study of trait effects on political behavior. American Political Science Review, 104, 85-110. doi:10.1017/S0003055409990359

Morgeson, F. P., Campion, M. A., Dipboye, R. L., Hollenbeck, J. R., Murphy, K., \& Schmitt, N. (2007). Reconsidering the use of personality tests in personnel selection contexts. Personnel Psychology, 60, 683-729. doi:10.1111/j.1744-6570.2007.00089.x

Morrell, K., \& Hartley, J. (2006). A model of political leadership. Human Relations, 59, 483-504. doi: $10.1177 / 0018726706065371$

Mudrack, P. E., \& Mason, E. S. (1995). Extending the Machiavellianism construct: A brief measure and some unexplored relationships. Journal of Social Behavior and Personality, 10, 187200.

Muthén, B. O. (1994). Multilevel covariance structure analysis. Sociological Methods \& Research, 22, 376-398. doi:10.1177/0049124194022003006

Muthén, L. K., \& Muthén, B. O. (2011). Mplus user's guide. Los Angeles, CA: The Authors.

O'Boyle, E. H., Forsyth, D. R., Banks, G. C., \& McDaniel, M. A. (2012). A meta-analysis of the dark triad and work behavior: A social exchange perspective. Journal of Applied Psychology, 97, 557579. doi:10.1037/a0025679

O'Connor, B. P. (2000). SPSS and SAS programs for determining the number of components using parallel analysis and Velicer's MAP test. Behavior Research Methods, Instruments, \& Computers, 32, 396-402. doi:10.3758/BF03200807

Ones, D. S., Dilchert, S., Viswesvaran, C., \& Judge, T. A. (2007). In support of personality assessment in organizational settings. Personnel Psychology, 60, 995-1027. doi:10.1111/j.1744-6570.2007. 00099. $\mathrm{x}$

Pfeffer, J. (2010). Power: Why some people have it - and others don't. New York, NY: Harper Collins.

Pillai, R., Williams, E. A., Lowe, K. B., \& Jung, D. I. (2003). Personality, transformational leadership, trust and the 2000 U.S. presidential vote. Leadership Quarterly, 14, 161-192. doi:10.1016/ S1048-9843(03)00008-0

Rubenzer, S. J., Faschingbauer, T. R., \& Ones, D. S. (2000). Assessing the U.S. presidents using the revised NEO Personality Inventory. Assessment, 7, 403-420. doi:10.1177/107319110000 700408

Salgado, J. F. (1997). The five factor model of personality and job performance in the European community. Journal of Applied Psychology, 82, 30-43. doi:10.1037/0021-9010.82.1.30

Sanchez, J. I., \& Levine, E. L. (2000). Accuracy or consequential validity: Which is the better standard for job analysis data? Journal of Organizational Behavior, 21, 809-818. doi:10.1002/ 1099-1379(200011)21:7<809::AID-JOB28>3.0.CO;2-O

Schmidt, F. L., \& Hunter, J. E. (2004). General mental ability in the world of work: Occupational attainment and job performance. Journal of Personality and Social Psychology, 86, 162-173. doi:10.1037/0022-3514.86.1.162

Shippmann, J. S., Ash, R. A., Battitsta, M., Carr, L., Eyde, L. D., Hesketh, B., ... Sanchez, J. I. (2000). The practice of competency modeling. Personnel Psychology, 53, 703-740. doi:10.1111/j. 1744-6570.2000.tb00220.x

Searing, D. (1994). Westminster's world: Understanding political roles. Cambridge, MA: Harvard University Press.

Silvester, J. (2008). The good, the bad and the ugly: Politics and politicians at work. International Review of Industrial and Organizational Psychology, 23, 107-148.

Silvester, J. (2012). Recruiting politicians: Designing competency-based selection for UK Parliamentary candidates. Chapter 2. In A. Weinberg (Ed.), Political leadership (pp. 21-38). Cambridge, UK: Cambridge University Press. 
Silvester, J., \& Dykes, C. (2007). Selecting political candidates: A longitudinal study of assessment centre performance and political success in the 2005 UK General Election. Journal of Occupational and Organizational Psychology, 80, 11-25. doi:10.1348/096317906X156287

Silvester, J., \& Menges, C. (2011). The political mentoring toolkit. London, UK: City University.

Silvester, J., \& Wyatt, M. (2012). Using 360-degree review to determine stakeholder perceptions of political leadership. Paper presented at the Society for Industrial and Organizational Psychology Annual Conference, San Diego.

Simonton, D. K. (1988). Presidential style: Personality, biography and performance. Personality Processes and Individual Differences, 55, 928-936. doi:10.1037/0022-3514.55.6.928

Simonton, D. K. (1998). Political leadership: Part 1 - world heads of state. Leadership Quarterly, 9, 239-242.

Simonton, D. K. (2006). Presidential IQ, openness, intellectual brilliance, and leadership: Estimates and correlations for 42 U.S. chief executives. Political Psychology, 27, 511-526. doi:10.1111/j.1467-9221.2006.00524.x

Simpson, J. (2008). The politics of leadership. London, UK: Leading Edge.

Spangler, W. D., \& House, R. J. (1991). Presidential effectiveness and the leadership motive profile. Journal of Personality and Social Psychology, 60, 439-455. doi:10.1037/0022-3514.60.3.439

Tabachnick, B. G., \& Fidell, L. S. (2001). Using multivariate statistics. Boston, MA: Allyn \& Bacon.

Tett, R. P., Guternamn, H. A., Bleier, A., \& Murphy, P. J. (2000). Development and content validation of a "hyperdimensional" taxonomy of managerial competence. Human Performance, 13, 205-251. doi:10.1207/S15327043HUP1303_1

Todd, S. Y., Harris, K. J., Harris, R. B., \& Wheeler, A. R. (2009). Career success implications of political skill. The Journal of Social Psychology, 149, 179-204. doi:10.3200/SOCP.149.3.279-304

Treadway, D. C. (2012). Political will in organizations. In G. R. Ferris \& D. C. Treadway (Eds.), Politics in organizations: Theory and research considerations (pp. 529-554). London, UK: Routledge.

Vecchione, M., \& Caprara, G. V. (2009). Personality determinants of political participation: The contribution of traits and self-efficacy beliefs. Personality and Individual Differences, 46, 487492.

Velicer, W. F. (1976). Determining the number of components from the matrix of partial correlations. Psychometrika, 41, 321-327.

Weinberg, A., \& Cooper, C. L. (2003). Stress among national politicians elected to Parliament for the first time. Stress and Health, 19, 111-117. doi:10.1002/smi.965

Winter, D. G. (1987). Leader appeal, leader performance, and the motive profile of leaders and followers: A study of American presidents and elections. Journal of Personality and Social Psychology, 50, 196-202. doi:10.1037/0022-3514.52.1.196

Winter, D. G. (1998). A motivational analysis of the Clinton first term and the 1996 presidential campaign. Leadership Quarterly, 9, 367-376.

Wisser, C., Atlink, W., \& Algera, J. (1997). From job analysis to work profiling: Do traditional procedures still apply? In N. Anderson \& P. Herriot (Eds.), Handbook of assessment and selection (pp. 115-131). New York, NY: John Wiley.

Received 5 July 2012; revised version received I6 August 2013 